\title{
Efficacy of Nisin in Treatment of Clinical Mastitis in Lactating Dairy Cows
}

\author{
L. T. Cao, ${ }^{*}$ J. Q. Wu, ${ }^{\star}$ F. Xie, ${ }^{*}$ S. H. Hu, ${ }^{* 1}$ and Y. Mot \\ *Department of Veterinary Medicine, Zhejiang University, Hangzhou 310029, China \\ †Da Bei Nong Research Institute of Agricultural Science and Technology, B110, No. 5 Kaituo Road, Shangdi, \\ Haidian District, Beijing 100085, China
}

\section{ABSTRACT}

Nisin is an antimicrobial polypeptide produced by Lactococcus lactis and is believed nontoxic to humans. The objective of this study was to evaluate a nisin-based formulation for the treatment of bovine clinical mastitis in lactating dairy cattle. A total of 92 cows with 107 clinically mastitic quarters were randomly assigned to nisin- (48 cows with 51 quarters) and gentamicin (GM)treated (44 cows with 56 quarters) groups. In the nisintreated group, cows received an intramammary infusion of nisin at a dose of 2,500,000 IU; in the GM-treated group, intramammary infusion of GM was administered at a dose of $0.8 \mathrm{~g}$. Results indicated that nisin offered a clinical cure rate similar to GM (90.2 vs. $91.1 \%$ ) and no difference in bacteriological cure rate than GM-treated group (60.8 vs. $44.6 \%$, respectively). Proportion of the quarters with milk somatic cell counts $<500,000$ cells $/ \mathrm{mL}$ was not different in the nisin-treated group (50.0 and 47.8\%) compared with the GM-treated group (33.3 and 37.3\%) 1 and 2 wk after treatment. Of 17 Staphylococcus aureus isolates, $82.5 \%$ were resistant to penicillin, and $35.3 \%$ to GM, but none of them to nisin. Nisin therapy eliminated $54.5 \%$ (6 of 11) of $S$. aureus IMI, whereas GM eliminated $33.3 \%$ (2 of 6). Nisin in milk ( $4.5 \pm 0.8 \mathrm{IU} / \mathrm{mL})$ was detected only at 12 $\mathrm{h}$ following intramammary infusion, which was much lower than the upper limit $(500 \mathrm{mg} / \mathrm{mL})$ allowed as preservative in milk by the China authority. Because of its efficacy in the treatment of bovine clinical mastitis, especially resistant Staph. aureus-caused IMI, as well as its safety in humans, nisin deserves further study to clarify its effects on mastitis caused by different mastitis pathogens on a larger scale.

Key words: clinical mastitis, nisin, therapy

\section{INTRODUCTION}

Bovine mastitis remains one of the most costly diseases in the dairy industry with economic losses esti-

Received March 1, 2007.

Accepted April 19, 2007.

${ }^{1}$ Corresponding author: Songhua@zju.edu.cn mated at $\$ 1.2$ to 1.7 billion (Wells and Ott, 1998) to dairy producers per year in the United States alone. Our recent investigation has shown that the annual incidence of clinical mastitis is about 56\% in a commercial dairy herd (Li et al., 2007), accounting for the highest incidence of all cattle diseases. Intramammary infusion of antibiotics is the main approach to treatment of mastitis on many dairy farms. Because of increased antibiotic resistance of mastitis pathogens (Hu et al., 1995; Wang et al., 2006), reduced responses to antibiotic therapy have become very common in veterinary practice. This situation has caused indiscriminate use of antibiotics with extralabeled doses by some veterinarians in their practice. Due to the extensive use of antibiotics on dairy farms, contamination of milk has become a subject of public concern. In addition, the quantity of antibiotics needed to eliminate mastitis pathogens inhibits the growth of lactic streptococci, the bacteria essential in cheese- or yogurt-making technology; and the residues in milk are a potential threat to human health. Consequently, there is an increasing need for alternative approaches to mastitis treatment.

Nisin is a natural antimicrobial peptide of 34 amino acids produced by Lactococcus lactis (Carr et al., 2002). The peptide was suggested effective against a wide range of gram-positive bacteria, including mastitis pathogens (Sears et al., 1992; Ryan et al., 1998; Wang et al., 2006). In the United States, nisin was confirmed to be generally recognized as safe (US Food and Drug Administration, 1988). Because of its high antibacterial activity and nontoxicity for humans, nisin has been used as a food preservative and is licensed by 48 countries around the world (Deegan et al., 2006). Nisin as an active ingredient was formulated into commercially available products for teat-dipping to prevent mastitis (Sears et al., 1992). Although much research has been completed regarding the antibacterial activities of nisin, the use of nisin for bovine mastitis therapy is lacking. Sears et al. (1995) reported an effective use of aqueous infusions of nisin in combination with lysostaphin in the treatment of bovine IMI experimentally induced with Staphylococus aureus, Streptococcus aga- 
lactiae, and Streptococcus uberis. The present study was designed to evaluate a nisin-based formulation for intramammary infusion for the treatment of clinical mastitis on a commercial dairy farm. Because gentamicin (GM) is the most commonly used antibiotic in the dairy herd where the present study was carried out, this antibiotic was used as a control drug. In addition, comparison was made between nisin and GM therapy for relieving inflammatory signs and eliminating IMI. The effects of nisin residues in milk on the fermentation by lactic streptococci were also evaluated.

\section{MATERIALS AND METHODS}

\section{Cows}

The study was conducted on a dairy farm in Hangzhou, Zhejiang Province, China, with approximately 1,000 Holstein dairy cows milked by machine 3 times daily. A total of 92 Holstein lactating cows (first lactation: $\mathrm{n}=8$; second lactation: $\mathrm{n}=18$; third lactation: $\mathrm{n}=$ 29; fourth lactation: $\mathrm{n}=21$; fifth lactation: 14 ; and sixth lactation: $\mathrm{n}=2$ ) with 107 quarters of naturally occurring clinical mastitis were used. The udder showed detectable swelling, was firm, and was associated with visibly abnormal mammary secretion and decreased milk production.

\section{Nisin-Based Formulation and Gentamicin}

Nisin Z (18,000 IU/mg) was supplied as Silver-Elephant Nisin by Zhejiang Silver-Elephant Bioengineering Co., Ltd. (Tiantai, Zhejiang, China). The nisin-based formulation mainly contained 2,500,000 IU of nisin Z, and the quantity of nisin used was based on our previous observation of nisin $\mathrm{Z}$ used at doses of $1,250,000$ IU, 2,500,000 IU, and 5,000,000 IU in the treatment of bovine clinical mastitis where the optimal dose was 2,500,000 IU for IMI (J. Q. Wu, unpublished data). Before treatment, nisin was dissolved in $20 \mathrm{~mL}$ of sterile physiological saline. Gentamicin was the product of Jilin Animal Health Products Co., Ltd. (Jilin, China).

\section{Treatments}

The mastitis cases were randomly divided into nisintreated and GM-treated groups. In the nisin-treated group (48 cows and 51 quarters), the cows received an intramammary infusion of nisin at a dose of 2,500,000 IU; in the GM-treated group (44 cows and 56 quarters), intramammary infusion of GM was administered at a dose of $0.8 \mathrm{~g}$. Before the treatment, each infected quarter was thoroughly milked out by hand and the teat end was cleaned using a cotton swab soaked with $70 \%$ alcohol. The treatment was performed twice daily (after morning and afternoon milkings) until the inflammatory signs disappeared and mammary secretion became visibly normal. The treatments were repeated $4.1 \pm$ 0.2 and $6.1 \pm 0.3$ times in groups of nisin and GM, respectively. The farm has its own veterinarians, and they were called immediately to treat the disease as soon as the stock keeper detected mastitis. Cows were observed for changes in milk and gland appearance at each milking during the treatment.

The results of treatment for evaluation of the therapeutic effects were categorized into 1) clinically cured, where inflammatory signs such as swelling, heat, and pain in the gland disappeared and production of the mammary secretion returned to a normal level; 2) bacteriologically cured, where no bacteria were detected from the milk samples following the treatment in addition to the clinical changes found in the above category; and 3) failed, where milk production did not return to normal, and no improved condition was found after 3 d of treatment.

\section{Milk Sample Collection and Analysis}

Fore-milk samples were aseptically collected from the affected mammary quarters immediately before initiating and at 1 and 2 wk after terminating treatments for bacteriological examination and SCC.

Bacteriological Examination. The milk sample was streaked on a blood agar plate and incubated for 24 to $48 \mathrm{~h}$ at $37^{\circ} \mathrm{C}$. After incubation, the plate was read for primary isolation of mastitis pathogens. A milk sample was considered contaminated when 3 or more colony types of bacteria were detected. And then, a single colony on the blood agar was inoculated into broth medium and incubated for 18 to $24 \mathrm{~h}$ at $37^{\circ} \mathrm{C}$. Further identification of specific bacterial species such as staphylococci, streptococci, and gram-negative bacteria was performed according to the methods described by the National Mastitis Council (1987).

SCC Analysis. For determination of SCC, milk samples were preserved with bronopol $(2 \mu \mathrm{L} / \mathrm{mL})$ after sample collection and analyzed using Integrated Milk Testing MilkoScan FT6000 (Foss; Beijing, China).

\section{Detection of Nisin Residues in Milk Following Intramammary Infusion in Clinically Mastitic Quarters}

To determine nisin residues in milk, quarter milk samples were aseptically collected at $12,36,48,60$, and $72 \mathrm{~h}$ after the last infusion of nisin at a dose of 2,500,000 IU for $3 \mathrm{~d}(\mathrm{n}=4)$. Nisin in milk samples was evaluated by the agar diffusion assay (Pongtharangkul and Demirci, 2004). Briefly, S1 agar containing 1.5\% (wt/vol) 
Tween 20 was autoclaved and cooled to $45^{\circ} \mathrm{C}$. An overnight culture of Micrococcus luteus (NCIB 8166) was added in a final concentration of $0.2 \%$ ( $\mathrm{vol} / \mathrm{vol}$ ). Precisely $210 \mathrm{~mL}$ of this suspension was poured into each sterile Petri plate $(280 \times 210 \mathrm{~mm})$. After that, plates were kept at room temperature for $2 \mathrm{~h}$ to allow agar solidification. The plates were stored at $4^{\circ} \mathrm{C}$ for $24 \mathrm{~h}$. Holes were bored on the plates using a 7-mm o.d. stainless steel borer. One hundred microliters of nisin standard solution (20, $40,80,160$, and $320 \mathrm{IU} / \mathrm{mL}$ ) were dispensed into each well. The plates were incubated at $30^{\circ} \mathrm{C}$ for a minimum of $20 \mathrm{~h}$ to give a well-defined inhibition zone. Seven wells were used for each nisin concentration. Using a caliper, inhibition zone diameters were measured to the nearest $0.1 \mathrm{~mm}$. The mean of the largest and smallest diameters was calculated for oval inhibition zones. A regression equation was calculated for inhibition zone diameter as a function of the log of nisin concentration.

\section{Evaluation of Nisin Residues in Milk on the Fermentation by Lactic Streptococci}

Two milk samples were aseptically collected from each of 4 mastitic cows at $12,24,36,48,60$, and $72 \mathrm{~h}$ after terminating treatments with nisin at a dose of 2,500,000 IU for $3 \mathrm{~d}$. One sample was from a nisintreated quarter, and the other was from untreated (clinically normal) quarters (composite milk samples). For the control, the same procedure was used to collect milk samples from other 4 mastitic cows treated with GM at a dose of $0.8 \mathrm{~g}$. The effect of drug residues in milk on the fermentation was evaluated by lactic streptococci, a commercial Direct Vat Set frozen dried starter culture mainly containing lactic streptococci (BF-101, Beijing Ferment Biology Co. Ltd., Beijing, China). It was inoculated into the milk samples and incubated at $43^{\circ} \mathrm{C}$ for $3.5 \mathrm{~h}$ to make yogurt. The yogurt quality was evaluated by its appearance and acidity.

\section{Susceptibility Test of Staph. aureus Isolates to Penicillin, Gentamicin, and Nisin}

Seventeen clinical isolates of Staph. aureus were obtained from the mastitic cows in this study. With a sterile loop, 4 to 5 colonies of Staph. aureus from a pure culture were picked up and suspended in $5 \mathrm{~mL}$ of sterile physiological saline. The bacterial suspension was adjusted to $1 \times 10^{8} \mathrm{cfu} / \mathrm{mL}$ according to the McFarland standard (Baron and Finegold, 1990). Three hundred fifty microliters of the suspension was inoculated on a nutrient agar plate. Susceptibility test disks were obtained commercially (Hangzhou Tian He Microorganism Reagent Co. Ltd., Hangzhou, China). After 0.5 h, disks containing $10 \mu \mathrm{g}$ of penicillin G, $10 \mu \mathrm{g}$ of gentami- cin, and $10 \mu \mathrm{g}$ of nisin $\mathrm{Z}$ were placed using a sterile forceps onto the agar surface and gently pressed down to ensure contact. Plates were incubated at $37^{\circ} \mathrm{C}$ for 20 h. Subsequently, the diameter of the zone of inhibition around each disk was measured. Susceptibility of the bacterial isolates was evaluated according to the guidelines outlined by Hangzhou Tian He Microorganism Reagent Co. Ltd., Hangzhou, China.

\section{Statistical Analysis}

The $\chi^{2}$ test for the effect of nisin-based formulation and conventional antibiotics was carried out using SAS 9.0 software for Windows (SAS Inst. Inc., Cary, NC).

\section{RESULTS}

\section{Cure Rates in Cows Treated with Nisin and GM}

Bacteriological cure rate $(60.8 \%)$ and the clinical cure rate $(90.2 \%)$ in the nisin-treated group were not different from those of GM-treated cows (44.6 and 91.2\%, respectively).

\section{Changes of Bacteria Detected in Milk Samples Before and After Treatments}

Of the bacteria isolated from the clinical mastitis cases, Strep. agalactiae and Staph. aureus were the predominant causative pathogens, being isolated from 37.4 and $15.9 \%$ of 107 cases, respectively (Table 1). Coagulase negative staphylococci seemed less important and only accounted for $9.3 \%$ of all cases.

For Staph. aureus mastitis, $54.5 \%$ of the cases (6 of 11) became bacteriologically negative after nisin treatment; meanwhile, only $33.3 \%$ ( 2 of 6 ) appeared negative in GM-treated cows after 2 wk (Table 1). For Strep. agalactiae mastitis, $83.3 \%$ (15 of 18) and 50.0\% (11 of 22) became bacteriologically negative in the cases treated by intramammary infusion of nisin and GM, respectively.

\section{SCC of Milk Samples from Mastitic Mammary Gland Infused with Nisin and GM}

Mammary quarters with milk SCC $<500,000$ cells/ $\mathrm{mL}$ were greater in the nisin-treated group (50.0 and 47.8\%) than in GM-treated group (33.3 and 37.3\%) 1 and 2 wk after treatment (Figure 1). However, there was no statistical difference.

\section{Persistence of Milk Residue Following Intramammary Infusion of Nisin for Mastitis Therapy}

Nisin $(4.5 \pm 0.8 \mathrm{IU} / \mathrm{mL})$ in milk was detected only at $12 \mathrm{~h}$ (Figure 2) following intramammary infusion of 
Table 1. Milk samples with positive bacteriological examination

\begin{tabular}{|c|c|c|c|c|c|c|}
\hline \multirow[b]{2}{*}{ Bacteria } & \multicolumn{3}{|c|}{$\begin{array}{c}\text { Nisin Z } \\
\text { (wk after treatment) }\end{array}$} & \multicolumn{3}{|c|}{$\begin{array}{c}\text { Gentamicin } \\
\text { (wk after treatment) }\end{array}$} \\
\hline & $0^{1}$ & 1 & 2 & $0^{1}$ & 1 & 2 \\
\hline Staphylococcus aureus & 11 & 6 & 5 & 6 & 5 & 4 \\
\hline CNS & 4 & 4 & 3 & 6 & 4 & 1 \\
\hline Streptococcus agalactiae & 18 & 4 & 3 & 22 & 13 & 11 \\
\hline Streptococcus dysagalactiae & 3 & 0 & 0 & 1 & 0 & 0 \\
\hline Streptococcus uberis & 0 & 0 & 0 & 1 & 1 & 1 \\
\hline Escherichia coli & 3 & 2 & 1 & 1 & 1 & 0 \\
\hline Others & 1 & 0 & 0 & 0 & 0 & 0 \\
\hline Two or more colony types detected & 6 & 0 & 0 & 6 & 2 & 2 \\
\hline Total & 46 & 16 & 12 & 43 & 26 & 19 \\
\hline
\end{tabular}

${ }^{1}$ Before treatment.

nisin at a dose of 2,500,000 IU twice daily for $3 \mathrm{~d}$ for mastitis therapy. After $3 \mathrm{~d}$, no nisin in milk was found.

\section{Effect of Nisin Residue in Milk on the Fermentation by Lactic Streptococci}

Reduced fermentation with low acidity from nisintreated cows with clinical mastitis was found in the milk from the treated quarters until $36 \mathrm{~h}$ following the last intramammary infusion, whereas no inhibition was detected in fermentation of the milk from untreated quarters throughout the experiment (Figure 3). But for GM-treated cows with clinical mastitis, the inhibited fermentation was found in the milk from treated and untreated quarters until $72 \mathrm{~h}$ following the last intramammary infusion with more inhibitory activity detected in the milk from GM-treated mammary quarters.

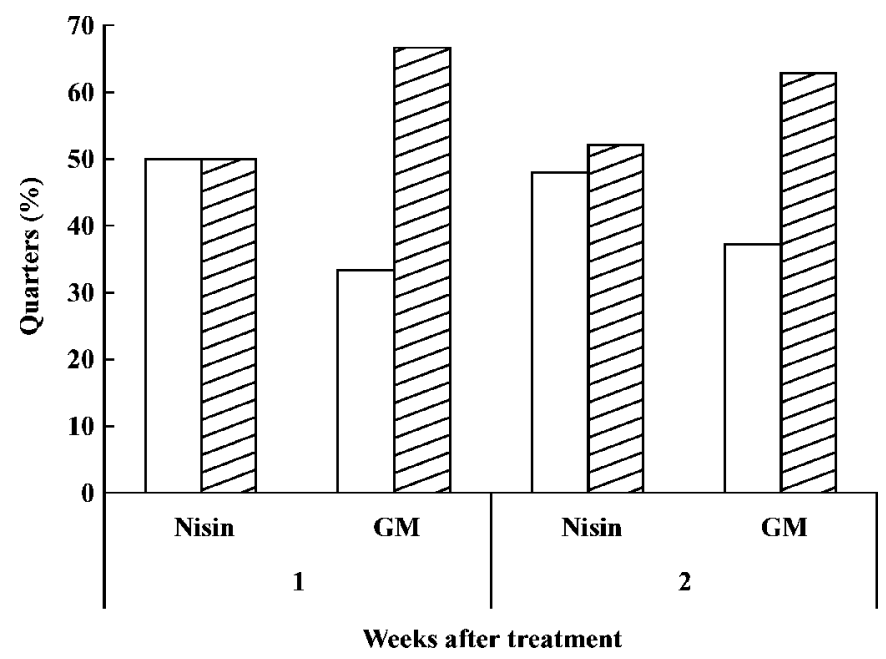

Figure 1. Quarters (\%) with milk SCC $<500,000 / \mathrm{mL}$ ( $\square$ ) or $\geq 500,000 / \mathrm{mL}$ (diagonal lines). Quarter milk samples were collected at 1 and 2 wk after the last infusion of nisin ( $\mathrm{n}=51$ quarters) or GM $(\mathrm{n}=56$ quarters) for the treatment of clinical mastitis.

\section{Antibiotic Resistance of Staph. aureus Isolated from Mastitic Cows}

Of 17 Staph. aureus isolates, the resistant isolates to penicillin, GM, and nisin were $82.5,35.3$, and $0 \%$, respectively.

\section{DISCUSSION}

Results from the present in vitro test showed that $82.5 \%$ of Staph. aureus isolates were resistant to penicillin. This caused the farm veterinarians to change use other antibiotics in an over-dose manner in their practice. Gentamicin was one of the first choices in this region. In addition, large amount of antibiotics used for mastitis therapy has led to increased public concern about milk contamination. Therefore, regulatory authorities have established the withdrawal period for veterinary antibiotics that must be observed by producers before the milk collected from the treated cows can

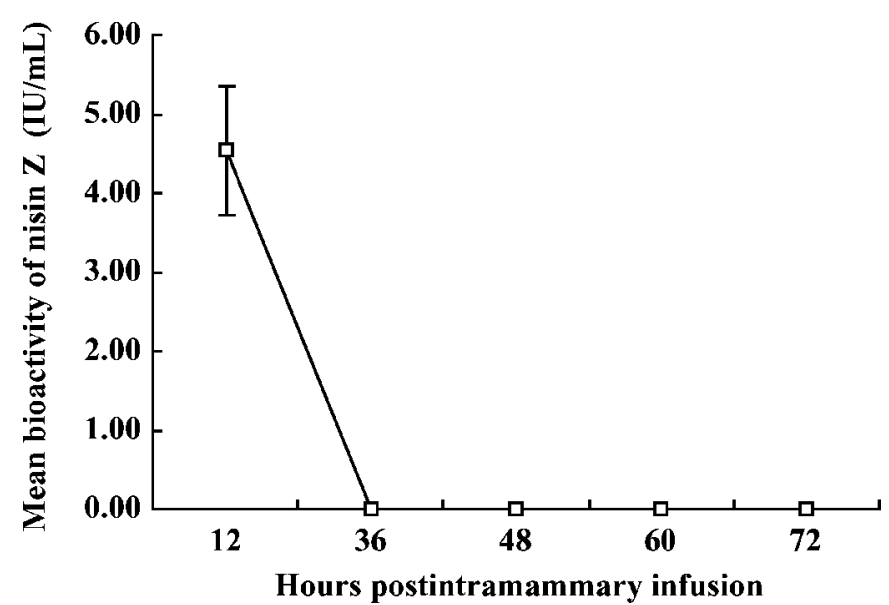

Figure 2. Nisin (IU/mL) in milk samples collected from clinically mastitic quarters ( $\mathrm{n}=4$ cows) $12,36,48,60$, and $72 \mathrm{~h}$ after intramammary infusion of nisin at a dose of 2,500,000 IU twice daily for $3 \mathrm{~d}$. 


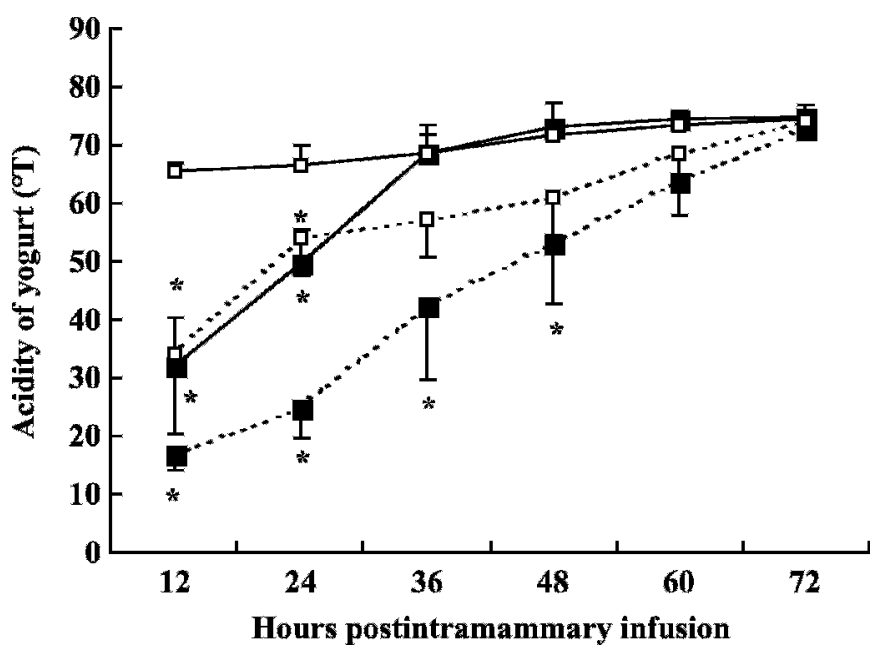

Figure 3. The acidity of yogurt made from milk samples collected from treated (ם) or untreated ( $\square$ ) quarters of clinically mastitic cows $12,24,36,48,60$, and $72 \mathrm{~h}$ after intramammary infusion of nisin (—; $\mathrm{n}=4$ cows) or gentamicin $(\cdots \cdots ; \mathrm{n}=4$ cows) twice daily for 3 d. Acidity or titratable acidity is the amount of $\mathrm{NaOH}$ needed to increase the $\mathrm{pH}$ of a given amount of yogurt to $\mathrm{pH} 8.4$ at which phenolphtalein changes color from colorless to pink. *Data differ when compared with $72 \mathrm{~h}$ after IMI within the same treatment group $(P<0.05)$.

be shipped to market (Ministry of Agriculture of the People's Republic of China, 2001). In China, fresh milk detected with antibiotics is not permitted for sale for human consumption (Ministry of Agriculture of the People's Republic of China, 2001). Yet, frequent change of antibiotics for IMI with extralabel use has prolonged the withdrawal period and increased the risk of antibiotic contamination in milk. In another study, we observed 5 cows $(13.2 \%)$ having excessive antibiotic residues after analysis of milk samples from 38 cows receiving intramammary infusion of GM (X. Tan, unpublished data). Large amounts of milk are discarded due to prolonged persistence of antibiotic residues in milk, which translates into more economic losses to the dairy farmers. To minimize antibiotic residues in milk and reduce economic losses, some alternative approaches were reported $(\mathrm{Hu}$ and $\mathrm{Du}, 1997 ; \mathrm{Hu}$ et al., 2001). In this study, a nisin-based formulation offered a similar therapeutic effect to GM in the treatment of bovine clinical mastitis, in both relieving the clinical signs and eliminating IMI with similar bacteriological cure rates than GM-treated group.

Treatment results of Staph. aureus mastitis are usually disappointing because of the shedding pattern of Staph. aureus in scar tissue and microabcesses (Sears et al., 1990). The cure rates for this type of mastitis vary considerably (Owens et al., 1988, 1997). In this study, Staph. aureus-infected quarters were reduced by $54.5 \%$ (6 of 11) after nisin treatment, but only 33.3\% (2 of 6) after GM treatment. For Strep. agalactiae mastitis, nisin treatment offered higher elimination of IMI $(83.3 \%, 15$ of 18$)$ than GM $(50.0 \%, 11$ of 22$)$. The higher cure rate in nisin group than in GM group could be attributed to causative bacteria not resistant to nisin, but to GM. To minimize the quantity of discarded milk and reduce the veterinarian's work, treatment usually stopped as soon as clinical signs disappeared and mammary secretion became visibly normal. In this study, the average frequencies of treatments by nisin and GM were $4.1 \pm 0.2$ and $6.1 \pm 0.3$, respectively. We thought that the cure rates would be higher if the cows had received more administration of the intramammary infusion to obtain sufficient antimicrobial treatment.

The advantage of nisin used for the treatment of clinical mastitis in lactating dairy cows is that its quantity sharply decreased to $4.5 \pm 0.8 \mathrm{IU} / \mathrm{mL}$ in $12 \mathrm{~h}$ and there was a trace at $36 \mathrm{~h}$ following intramammary infusion. The reason for sharp decrease of nisin may be due to the increased enzymatic activity in mastitic milk (Mehrzad et al., 2005), which degrades the antimicrobial peptide. According to the Hygienic Standards for the Use of Food Additives (Ministry of Public Health of the People's Republic of China, 1996), nisin as a preservative in milk is suggested at $10 \mathrm{IU} / \mathrm{mL}$, with an upper limit of $500 \mathrm{IU} / \mathrm{mL}$. Therefore, the withdrawal period for nisin used for mastitis treatment is almost zero because its residue in milk is much lower than the upper limit permitted.

When GM was used to treat clinical mastitis, lower fermentation by lactic streptococci was found in the milk from treated and untreated quarters until $72 \mathrm{~h}$ following the last intramammary infusion. This result indicated that GM may move from an inflamed mammary gland to another to make the milk of untreated quarters contaminated (Sweeney et al., 1996). When nisin was used to treat clinical mastitis, poor fermentation was found only in the milk from the treated quarters for $36 \mathrm{~h}$ following the last intramammary infusion, whereas no inhibition was detected in the milk from the untreated quarters (Figure 3). This result indicated that nisin, with its relatively large molecule, may not move from an inflamed mammary gland to another. Interestingly, inhibition remained in the milk from treated quarters at 12 and $24 \mathrm{~h}$, although only $4.5 \pm$ $0.8 \mathrm{IU} / \mathrm{mL}$ or a trace of nisin was detected at those time points. The reduced yogurt fermentation may result from high milk SCC (Vivar-Quintana et al., 2006) found within $36 \mathrm{~h}$ after mastitis treatment.

In this study, $82.5 \%$ of Staph. aureus isolates were found resistant to penicillin, and $35.3 \%$ to GM, but none to nisin. Similar results were observed in a study on cross-resistance between nisin and 33 other antimicrobials where penicillin-resistant Staph. aureus was 50 
times more sensitive to nisin (Szybalski, 1953). Nisin inhibited target cells by forming pores in the membrane, depleting the transmembrane potential and the $\mathrm{pH}$ gradient, resulting in the leakage of cellular materials.

\section{CONCLUSIONS}

The nisin-based formulation used in this study was effective in the treatment of clinical mastitis in lactating dairy cows caused by several different mastitis pathogens on a commercial dairy farm. Intramammary infusions of nisin at a dose of 2,500,000 IU with an average of 4.1 administrations in the treatment of 51 clinical mastitis cases resulted in bacteriological and clinical cure rates of 60.8 and $90.2 \%$, respectively; meanwhile, intramammary infusions of GM at a dose of $0.8 \mathrm{~g}$ with an average of 6.1 administrations in the treatment of 56 clinical mastitis cases resulted in no difference in bacteriological and clinical cure rates of 44.6 and $91.1 \%$, respectively. Of 17 Staph. aureus isolates from clinical mastitis cases, $82.5 \%$ of them were resistant to penicillin, $35.3 \%$ to GM, and none to nisin. Nisin treatment eliminated $54.5 \%$ (6 of 11) of Staph. aureus IMI, whereas GM eliminated $33.3 \%$ (2 of 6 ). Nisin $(4.5 \pm 0.8 \mathrm{IU} / \mathrm{mL})$ in milk was detected only at $12 \mathrm{~h}$ following intramammary infusion. Because of its efficacy in the treatment of bovine clinical mastitis, especially mastitis caused by antibiotic-resistant strains of Staph. aureus, as well as its safety in humans, nisin deserves further study to clarify its effects on mastitis caused by different mastitis pathogens on a larger scale.

\section{ACKNOWLEDGMENTS}

The financial supports from the Department of Science and Technology of Zhejiang Province (2005C22035, 2005C12015) and from Da Bei Nong Group are gratefully acknowledged.

\section{REFERENCES}

Baron, E. J., and S. M. Finegold. 1990. Method for Testing Antimicrobial Effectiveness. Pages 171-194 in Bailey \& Scott's Diagnostic Microbiology. 6th ed. Mosby, St. Louis, MO.

Carr, F. J., D. Chill, and N. Maida. 2002. The lactic acid bacteria: A literature survey. Crit. Rev. Microbiol. 28:281-370.

Deegan, L. H., P. D. Cotter, C. Hill, and P. Ross. 2006. Bacteriocins: Biological tools for bio-preservation and shelf-life extension. Int. Dairy J. 16:1058-1071.

Hu, S. H., W. M. Cai, and A. F. Du. 1995: Mastitis causing bacteria in dairy cows in Hangzhou and their sensitivity to some antibiot- ics. Page 84 in Proc. XXV Congr. World Vet. Assoc., 3-9 September 1995, Yokohama, Japan.

Hu, S., C. Concha, A. Johannisson, G. Meglia, and K. P. Waller. 2001. Effect of subcutaneous injection of ginseng on cows with subclinical Staphylococcus aureus mastitis. J. Vet. Med. B. 48:519-528.

Hu, S. H., and A. F. Du. 1997. Treatment of bovine mastitis with Houttuynin sodium bisulphate. J. Vet. Med. B. 44:365-370.

Li, J. P., L. T. Cao, and S. H. Hu. 2007. Major diseases and drugs in a commercial dairy herd. Chin. J. Vet. Med. (accepted)

Mehrzad, J., C. Desrosiers, K. Lauzon, G. Robitaille, X. Zhao, and P. Lacasse. 2005. Proteases involved in mammary tissue damage during endotoxin-induced mastitis in dairy cows. J. Dairy Sci. 88:211-222.

Ministry of Agriculture of the People's Republic of China. 2001. Agricultural Standards for Fresh Milk (NY 5045-2001). Standards Press of China, Beijing, China.

Ministry of Public Health of the People's Republic of China. 1996 Hygienic Standards for the Use of Food Additives (GB 2760-1996). Standards Press of China, Beijing, China.

National Mastitis Council. 1987. Sample Collection and Handling. Pages 11-19 in Laboratory and Field Handbook on Bovine Mastitis. Natl. Mastitis Counc. Inc., Arlington, VA.

Owens, W. E., C. H. Ray, R. L. Boddie, and S. C. Nickerson. 1997. Efficacy of sequential intramammary antibiotic treatment against chronic $S$. aureus intramammary infections. Large Anim. Pract. 18:10-14.

Owens, W. E., J. L. Watts, R. L. Boddie, and S. C. Nickerson. 1988. Antibiotic treatment of mastitis: Comparison of intramammary and intramammary plus intramuscular therapies. J. Dairy Sci. 71:3143-3147.

Pongtharangkul, T., and A. Demirci. 2004. Evaluation of agar diffusion bioassay for nisin quantification. Appl. Microbiol. Biotechnol. 65:268-272.

Ryan, M. P., W. J. Meaney, R. P. Ross, and C. Hill. 1998. Evaluation of lacticin 3147 and a teat seal containing this bacteriocin for inhibition of mastitis pathogens. Appl. Environ. Microbiol. 64:2287-2290

Sears, P. M., J. Peele, M. Lassauzet, and P. Blackburn. 1995. Use of antimicrobial proteins in the treatment of bovine mastitis. Pages 17-18 in Proc. 3rd Int. Mastitis Sem., Tel Aviv, Israel. A. Saran and S. Soback ed. Int. Dairy Fed., Brussels, Belgium.

Sears, P. M., B. S. Smith, P. B. Englisch, P. S. Herer, and R. N Gonzalez. 1990. Shedding pattern of Staphylococcus aureus from intramammary infections. J. Dairy Sci. 73:2785-2789.

Sears, P. M., B. S. Smith, W. K. Stewart, R. N. Gonzalez, S. D. Rubino, S. A. Gusik, E. S. Kulisek, S. J. Projan, and P. Blackburn. 1992. Evaluation of a nisin based germicidal formulation on teat skin of live cows. J. Dairy Sci. 75:3185-3190.

Sweeney, R. W., M. A. Fennell, C. M. Smith, and P. C. Bardalaye. 1996. Systemic absorption of gentamicin following intramammary administration to cows with mastitis [correction of mastititis]. J. Vet. Pharmacol. Ther. 19:155-157.

Szybalski, W. 1953. Genetic studies on microbial cross resistance to toxic agents. Antibiot. Chemother. 3:1095-1103.

US Food and Drug Administration. 1988. Nisin preparation: Affirmation of GRAS status as direct human food ingredient. Federal Register 53, April 6.

Vivar-Quintana, A. M., E. Beneitez De La Mano, and I. Revilla. 2006. Relationship between somatic cell counts and the properties of yoghurt made from ewes' milk. Int. Dairy J. 16:262-267.

Wang, F., L. T. Cao, and S. H. Hu. 2006. In vitro inhibitory effect of nisin on major pathogenic bacteria of bovine mastitis. Chin. J. Vet. Drug 40:12-16. (in Chinese)

Wells, S. J., and S. L. Ott. 1998. What is the current milk quality in the U.S.? Pages 10-18 in 1998 Natl. Mastitis Counc. Annu. Meet. Proc. Natl. Mastitis Counc., Madison, WI. 